\title{
PENERAPAN MODEL PEMBELAJARAN DIRECT IINSTRUCTION (DI) TERHADAP PRESTASI BELAJAR MAHASISWA PRODI PENDIDIKAN TIK IKIP PGRI PONTIANAK
}

\author{
Utin Desy Susiaty \\ IKIP PGRI Pontianak \\ e-mail: d3or4f4ty4@gmail.com
}

\begin{abstract}
Abstrak
Tujuan penelitian ini untuk mengetahui peningkatan prestasi belajar mahasiswa sesudah diberikan model pembelajaran DI. Penelitian ini merupakan penelitian kuasi eksperimen. Teknik pengumpulan data meliputi metode tes untuk data untuk nilai prestasi belajar mahasiswa. Uji hipotesis penelitian menggunakan analisis n-gain (analisis before-after). Berdasarkan hasil penelitian dapat disimpulkan bahwa terdapat peningkatan prestasi belajar mahasiswa sesudah diberikan model pembelajaran DI. Hasil dari analisis skor gain ternormalisasi diperoleh 2 mahasiswa $(6,25 \%)$ mendapatkan skor gain tinggi, 14 mahasiswa (43,75\%) mendapatkan skor gain sedang dan 16 mahasiswa (50\%) mendapatkan skor gain rendah serta skor gain ratarata keseluruhan mahasiswa sebesar 0,26 yang berkategori rendah.

Kata kunci: direct instruction, penerapan, prestasi belajar

\section{Abstract}

The aims of this study were to investigate the improvement of student achievement after given DI model. This research used quasi experimental research. The data collection technique was include test methods for data for student achievement. The data was analyzed using n-gain analyzed (before-after analyzed). Based on these results it can be concluded there is improvement of student achievement after given DI model. The result of the normalized gain score analysis obtained 2 students (6.25\%) got high gain score, 14 students (43,75\%) got medium gain score and 16 student (50\%) got low gain score and overall average gain score students of 0.26 are categorized as low.
\end{abstract}

Keywords: application, direct instruction, learning achievement

\section{PENDAHULUAN}

Pendidikan adalah usaha sadar untuk menyiapkan peserta didik agar dapat berperan aktif dan positif dalam hidupnya sekarang dan yang akan datang. Pendidikan nasional Indonesia adalah pendidikan yang berakar pada kebudayaan bangsa Indonesia dan berdasar kepada pencapaian tujuan pembangunan nasional Indonesia. Sistem pendidikan nasional (Sisdiknas) merupakan satu keseluruhan yang terpadu dari semua satuan dan kegiatan pendidikan yang saling berkaitan untuk mengusahakan tercapainya tujuan pendidikan nasional (Tirtarahardja dan Sulo, 2015:263).

Penyusunan standar proses pendidikan diperlukan untuk menentukan kegiatan pembelajaran yang dilakukan oleh pendidik sebagai upaya ketercapaian Standar 
Kompetensi Lulusan. Dengan demikian, standar proses dapat dijadikan pedoman oleh setiap pendidik dalam pengelolaan proses pembelajaran serta menentukan komponenkomponen yang dapat mempengaruhi proses pendidikan. Salah satu pendekatan yang dapat digunakan untuk menentukan kualitas proses pendidikan adalah pendekatan sistem. Melalui pendekatan sistem kita dapat melihat berbagai aspek yang dapat mempengaruhi keberhasilan suatu proses (Sanjaya, 2013:49).

Masyarakat terdidik dan masyarakat yang cerdas, dapat dibangun dan dibentuk dengan merubah paradigma dan sistem pendidikan. Formalitas dan legalitas tetap saja menjadi sesuatu yang penting, akan tetapi perlu diingat bahwa substansi juga bukan sesuatu yang bisa diabaikan hanya untuk mengejar tataran formal saja. Maka yang perlu dilakukan sekarang bukanlah menghapus formalitas yang telah berjalan melainkan menata kembali sistem pendidikan yang ada dengan paradigma baru yang lebih baik. Dengan paradigma baru, praktik pembelajaran akan digeser menjadi pembelajaran yang lebih bertumpu pada teori kognitif dan konstruktivistik. Pembelajaran akan berfokus pada pengembangan kemampuan intelektual yang berlangsung secara sosial dan kultural, mendorong peserta didik membangun pemahaman dan pengetahuannya sendiri dalam konteks sosial, dan belajar dimulai dari pengetahuan awal dan perspektif budaya. Tugas belajar didesain menantang dan menarik untuk mencapai derajat berpikir tingkat tinggi (Kamdi dalam Aunurrahman, 2013:2).

Keberhasilan proses pembelajaran tidak terlepas dari kemampuan pendidik mengembangkan model-model pembelajaran yang berorientasi pada peningkatan intensitas keterlibatan peserta didik secara efektif di dalam proses pembelajaran. Pengembangan model pembelajaran yang tepat pada dasarnya bertujuan untuk menciptakan kondisi pembelajaran yang memungkinkan peserta didik dapat belajar secara aktif dan menyenangkan sehingga peserta didik dapat meraih hasil belajar dan prestasi yang optimal.

Pengembangan model pembelajaran yang efektif diperlukan setiap pendidik harus memiliki pengetahuan yang memadai berkenaan dengan konsep dan cara-cara pengimplementasian model-model tersebut dalam proses pembelajaran. Model pembelajaran yang efektif memiliki keterkaitan dengan tingkat pemahaman pendidik terhadap perkembangan dan kondisi peserta didik di kelas. Demikian juga pentingnya pemahaman pendidik terhadap sarana dan fasilitas sekolah yang tersedia, kondisi kelas dan beberapa faktor lain yang terkait dengan pembelajaran. Tanpa pemahaman terhadap berbagai kondisi ini, model yang dikembangkan pendidik cenderung tidak dapat meningkatkan peran serta peserta didik secara optimal dalam pembelajaran, dan pada akhirnya tidak dapat memberi sumbangan yang besar terhadap pencapaian hasil belajar peserta didik (Aunurrahman, 2013:140). 
Model-model pembelajaran yang dipilih dan dikembangkan pendidik hendaknya dapat mendorong peserta didik untuk belajar dengan mendayagunakan potensi yang mereka miliki secara optimal. Belajar yang kita harapkan bukan sekedar mendengar, memperoleh atau menyerap informasi yang disampaikan pendidik. Belajar harus menyentuh kepentingan peserta didik secara mendasar. Belajar harus dimaknai sebagai kegiatan pribadi peserta didik dalam menggunakan potensi pikiran dan nuraninya baik terstruktur maupun tidak terstruktur untuk memperoleh pengetahuan, membangun sikap dan memiliki keterampilan tertentu. Dalam sebuah situs tentang pembelajaran Huitt (dalam Aunurrahman, 2013:141), mengemukakan raisonalitas pengembangan model pembelajaran. Model-model pembelajaran dikembangkan utamanya beranjak dari adanya perbedaan berkaitan dengan berbagai karakteristik peserta didik. Karena peserta didik memiliki berbagai karakteristik kepribadian, kebiasaan-kebiasaan, modalitas belajar yang bervariasi antara individu satu dengan yang lain, maka model pembelajaran pendidik juga harus selayaknya tidak terpaku hanya pada model tertentu, akan tetapi harus bervariasi. Di samping didasari pertimbangan keragaman peserta didik, pengembangan berbagai model pembelajaran juga dimaksudkan untuk menumbuhkan dan meningkatkan motivasi belajar peserta didik, agar mereka tidak jenuh dengan proses belajar yang sedang berlangsung. Itulah sebabnya maka di dalam menentukan model-model pembelajaran yang akan dikembangkan, pendidik harus memiliki pemahaman yang baik tentang siswa-siswanya, keragaman kemampuan, motivasi, minat dan karakteristik pribadi lainnya (Aunurrahman, 2013:141-142).

Pembelajaran pada dasarnya adalah proses penambahan informasi dan kemampuan baru. Ketika seorang pendidik berpikir informasi dan kemampuan apa yang akan diberikan kepada peserta didik, maka pada saat itu juga, seorang pendidik harus memikirkan model apa yang akan digunakan agar proses pembelajaran dapat dicapai secara efektif dan efisien (Sanjaya, 2008). Hal ini sangat penting untuk dipahami, sebab tujuan pembelajaran yang akan dicapai sangat menentukan bagaimana caara mencapainya. Model, metode atau strategi pembelajaran yang akan digunakan dalam proses pembelajaran merupakan hal yang sangat penting diperhatikan pendidik. Karena akan menentukan kesiapan dan kemampuan siswa dalam menyerap ilmu yang akan dipelajari (Zahriani, 2014:95).

Salah satu model pembelajaran adalah model pembelajaran DI (pembelajaran langsung). Menurut Arends (dalam Karo-Karo, 2014:2) model pengajaran langsung adalah salah satu pendekatan mengajar yang dirancang khusus untuk menunjang proses belajar peserta didik yang berkaitan dengan pengetahuan deklaratif dan pengetahuan prosedur yang terstruktur dengan baik yang dapat diajarkan dengan pola kegiatan yang bertahap, selangkah demi selangkah. DI merupakan pendekatan pembelajaran dimana pendidik 
memberikan pelajaran dalam susunan dan langkah-langkah sederhana dan berurutan. DI efektif digunakan dalam pembelajaran manapun karena didasarkan pada prinsip-prinsip pembelajaran tingkah laku, seperti mendapatkan perhatian peserta didik, memperkuat respon yang benar, memberikan umpan balik dan korektif pada siswa, serta mempraktekkan pengetahuan yang diperoleh dengan benar (Burden dan Byrd, 2003). Dalam artian penerapan DI merupakan pembelajaran modelling dimana pendidik berperan sebagai model dan membimbing siswa dalam menguasai pengetahuan terutama yang berhubungan dengan keterampilan dan konsep. Pada materi-materi tertentu seperti matematika, komputer, membaca kode, sains, konsep dan aturan, bahasa asing, kosa kata dan grammar sangat tepat menggunakan model pembelajaran DI. Karena siswa membutuhkan bimbingan pendidik untuk menguasai keterampilan, konsep dan prosedur tersebut langkah demi langkah secara terstruktur (Zahriani, 2014:96).

Penelitian terdahulu dengan menggunakan model pembelajaran DI menunjukkan peningkatan prestasi belajar peserta didik. Beberapa penelitian tersebut yaitu penelitian yang dilakukan oleh Susiana dan Wening (2015) diperoleh hasil pencapaian kompetensi kelas eksperimen setelah menerapkan model pengajaran langsung berbantuan multimedia pada pembelajaran pembuatan desain busana lebih dari $75 \%$ peserta didik telah mencapai tuntas. Sependapat dengan penelitian yang dilakukan oleh Setiawan, dkk (2010) diperoleh bahwa model DI berhasil dan efektif dalam meningkatkan pemahaman belajar siswa. Dengan penerapan model DI, tidak ditemukan perbedaan efektifitas yang signifikan terhadap peningkatan pemahaman belajar berdasarkan tingkat prestasi siswa kelompok atas dan kelompok bawah dalam pembelajaran RPL di SMK. Sehingga, dengan model DI, pengetahuan dan keterampilan dapat diterima dan terserap dengan baik oleh seluruh siswa. Proses pembelajaran RPL dengan model DI ternyata membantu siswa lebih fokus dan kreatif. Uraian tersebut mendasari perlunya penelitian penerapan model pembelajaran DI pada tingkat perpendidikan tinggi dengan harapan dapat meningkatkan pemahaman yang berakibat meningkatnya prestasi belajar mahasiswa khususnya mahasiswa program pendidikan teknologi dan informasi IKIP PGRI Pontianak.

\section{METODE}

Penelitian ini termasuk penelitian eksperimen yang bertujuan untuk mengetahui peningkatan prestasi belajar mahasiswa sesudah diberikan model pembelajaran DI. Metode penelitian eksperimen dapat diartikan sebagai metode penelitian yang digunakan untuk mencari pengaruh perlakuan tertentu terhadap yang lain dalam kondisi yang terkendalikan. Bentuk desain eksperimen yang digunakan dalam penelitian ini adalah Quasi Experimental Designs dengan bentuk Time Series Design (Sugiyono, 2014:72-78). 
Populasi dalam penelitian ini adalah seluruh mahasiswa semester III kelas sore Program Studi Pendidikan Teknologi Informasi dan Komputer IKIP PGRI Pontianak yang mengambil mata kuliah Matematika Diskrit tahun akademik 2016/2017. Pengambilan sampel dilakukan dengan teknik purposive sampling. Sampel dalam penelitian ini adalah mahasiswa semester III kelas B sore Program Studi Pendidikan Teknologi Informasi dan Komputer IKIP PGRI Pontianak yang mengambil mata kuliah Matematika Diskrit tahun akademik 2016/2017.

Pengumpulan data pada penelitian ini menggunakan metode tes. Pengujian hipotesis penelitian untuk mengetahui seberapa besar peningkatan prestasi belajar mahasiswa sesudah diberikan model pembelajaran DI, menggunakan analisis n-gain (analisis before-after) mengacu pada Hake (Ain, 2013:99).

\section{HASIL DAN PEMBAHASAN}

Hasil analisis diperoleh bahwa terdapat terdapat peningkatan prestasi belajar mahasiswa yang signifikan, selanjutnya untuk mengetahui seberapa besar peningkatan tersebut dilakukan perhitungan skor gain ternormalisasi yang didapatkan seperti Tabel 1.

Tabel 1. Hasil Perhitungan Skor Gain Ternormalisasi

\begin{tabular}{lccc}
\hline \multicolumn{1}{c}{ Skor Gain } & Kategori & Jumlah Siswa & Persentase \\
\hline $\boldsymbol{g}<\mathbf{0 , 3}$ & Rendah & 16 & $50 \%$ \\
$\mathbf{0 , 3} \leq \boldsymbol{g} \leq \mathbf{0 , 7}$ & Sedang & 14 & $43,75 \%$ \\
$\boldsymbol{g}>\mathbf{0 , 7}$ & Tinggi & 2 & $6,25 \%$ \\
\hline
\end{tabular}

Hasil penelitian tersebut tidak sejalan dengan beberapa penelitian terdahulu tentang DI. Penelitian yang dilakukan oleh Karo-Karo (2014) diperoleh bahwa model pembelajaran langsung memberikan dampak positif dalam meningkatkan prestasi belajar siswa dengan kategori tinggi. Susiana dan Wening (2015) menyatakan bahwa melalui penggunaan model DI berbantuan multimedia, motivasi belajar dan pencapaian kompetensi masuk kriteria tinggi. Penelitian Setiawan, et.al (2010) menunjukkan bahwa pembelajaran RPL dengan model DI berhasil dan efektif dalam meningkatkan pemahaman belajar siswa. Perbedaan hasil penelitian tersebut dikarenakan untuk tingkatan mahasiswa model pembelajaran DI kurang merangsang kemampuan mahasiswa yang dapat meningkatkan prestasi belajarnya. Walaupun terdapat peningkatan yang signifikan, namun peningkatan tersebut belum mencapai hasil yang maksimal.

\section{SIMPULAN}

Hasil analisis data dari penelitian yang dilakukan serta mengacu pada perumusan masalah pada penelitian ini, dapat disimpulkan bahwa terdapat peningkatan prestasi belajar mahasiswa sesudah diberikan model pembelajaran DI. Hasil dari analisis skor gain 
ternormalisasi diperoleh 2 mahasiswa (6,25\%) mendapatkan skor gain tinggi, 14 mahasiswa (43,75\%) mendapatkan skor gain sedang dan 16 mahasiswa (50\%) mendapatkan skor gain rendah serta skor gain rata-rata keseluruhan mahasiswa sebesar 0,26 yang berkategori rendah.

\section{DAFTAR PUSTAKA}

Ain, T.N. 2013. Pemanfaatan Viasualisasi Video Percobaan Gravity Current untuk Meningkatkan Pemahaman Konsep Fisika pada Materi Tekanan Hidrostatis. Jurnal Inovasi Pendidikan Fisika, 2(2):97-102.

Aunurrahman. 2013. Belajar dan Pembelajaran. Bandung: Alfabeta.

Burden, P.R. dan Byrd. D. M, 2003. Method for Effective Theaching. Pearson Education, USA.

Karo, K.A. 2014. Penerapan Model Pembelajaran Langsung untuk Meningkatkan Aktivitas Belajar Siswa pada Mata Pelajaran Penjaskes di Kelas X-1 SMA Negeri 12 Medan T.A 2012/2013. Jurnal Saintech, 6(2): 1-9.

Sanjaya, W. 2013. Strategi Pembelajaran Berorientasi Standar Proses Pendidikan. Jakarta: Kencana.

Setiawan, W., Fitrajaya, E., \& Mardiyanti, T. 2010. Penerapan Model Pembelajaran Langsung (Direct Instruction) untuk Meningkatkan Pemahaman Belajar Siswa dalam Pembelajaran Rekayasa Perangkat Lunak. Jurnal Pendidikan Teknologi Informasi dan Komunikasi (PTIK), 3(1): 7-10.

Sugiyono. 2014. Metode Penelitian Kuantitatif, Kualitatif, dan R\&D. Bandung: Alfabeta.

Susiana, R \& Wening, S. 2015. Pengaruh Model Direct Instruction Berbantuan Multimedia terhadap Motivasi Belajar dan Pencapaian Kompetensi Pembuatan Desain Busana. Jurnal Pendidikan Vokasi, 5(3): 377-393.

Tirtarahardja, U \& Sulo, L.L. 2015. Pengantar Pendidikan (edisi revisi). Jakarta: PT Rineka Cipta.

Zahriani. 2014. Kontektualisasi Didalam Pembelajaran Sains. Lantanida Journal, 1(1): 95106. 